\title{
Strategy Implementation in Bank Performance Achievement Based on The Balanced Scorecard
}

\author{
Rieke Sri Rizki Asti Karini \\ www.rsrak17@yahoo.com \\ STIP Yapari Aktripa
}

\begin{abstract}
The purpose of this research was to know the influence of strategy implementation to the performance achievement of bank based on the balanced scorecard. The research had been done on Branch Office (BO) of Bank Bjb in West Java. Explanatory case study type was used as the research design. The population included all the functional managers (heads of division) of all BO of Bank Bjb in West Java. There were 48 heads of division in 16 BO with purposive sampling method. Data type was cross-section and questionnaire that were given to three functional managers. Path analysis was used. The result showed that the strategy implementation which had been done in credit management, credit supervision and recovery management, also fund and service management, simultaneously and partially had positive influence in the performance achievement of bank based on the balanced scorecard.
\end{abstract}

Keywords: strategy implementation, credit management, credit supervision and recovery management, fund \& service management, balanced scorecard

\section{INTRODUCTION}

Undang-Undang No. 24 of 2004 on the financial balance between Central Government and Regional Government and Undang-Undang No. 9 of 2015 on regional government stated that the performance of regional government was influenced by the direction of fiscal and monetary policy, therefore that the measurement of regional economic performance cannot be separated from the banking sector. Bank is a real form of government investment and business world. The role of collecting and distributing funds from and to the community is expected to be a trigger of the economic activity in a region, which resulted in Bank Indonesia not providing assistance to third parties, either the government or the business world (small businesses). Achyar Iljas (2012:18) stated that the implementation of regional autonomy through central and regional balance funds is an excellent complement factor. Lack of financing sources, especially for small and medium enterprises, can be covered partially by liquidity due to the flow of funds derived from the balancing funds. This is evident from the higher banking liquidity, especially in BPD with the dropping of balancing fund.

Bank management faced the problem of business competition in the region in maintaining its performance. According to Mardiasmo (2015: 385) in the era of regional autonomy, regional governments are no longer obliged to use one bank (BPD) for regional financial affairs. In principle, regional governments can work with banks that provide the greatest benefits to regional governments, whether BPD, BRI or others.

In order to achieve the company's performance goals, managers must have the ability to develop and execute management strategies appropriately (Jauch and Glueck, 2013:5; Wheelen and Hunger, 2015:14). The use of performance appraisal methods is critical to the successful achievement of bank performance goals. According to Nurmadi H. Sumarta (2013:49), important corporate performance appraisals are performed by management, shareholders, government or other interested parties and related to the distribution of welfare among them, including banks.

Assessment of the performance of bank companies related to bank soundness based on Director Decree of Bank Indonesia 13/1/ PBI/2011 dated January 5, 2011 regarding the rating of commercial bank health that bank is required to conduct bank rating based on risk-based bank rating. Assessment of bank health is performed on the bank individually or consolidated. The bank appraisal stage at RGEC (Risk Profile, Good Corporate Governance, Earning, and Capital) is called the bank health model that is full of risk management. To that end, bank management needed to pay attention 
to general principles of risk-oriented, proportionality, materiality and significance, as well as comprehensive and structured as the foundation in assessing bank health. Aspects of bank soundness rating were based on financial and non-financial performance indicators of bank companies, therefore the performance scoring method of balanced scorecard is used (Kaplan and Norton, 2015: 2; Ittner and Larcker, 2014; Nanni, et.al., 2012; Shank and Govidarajan, 2015; Wughanga, 2010; D'Souzo, 2007; Ozturk \& Coskun, 2014).

Utilization of measurement of performance achievement of manufacturing and service companies in Indonesia with balanced scorecard is still rare. Although many companies in the USA have been successful in using it to double the company's financial performance (Anthony, 2014, Hansen and Mowen, 2017), few Indonesian companies have the courage to experiment in implementing the balanced scorecard to boost the company's ability to deliver financial performance (Mulyadi, 2015: 22).

The national companies experienced the phenomenon, especially banking, so that the use of balanced scorecard method approach can be used as a consideration of the bank managers to measure the achievement of their performance. Various researches were conducted on the implementation of functional management strategy, the implementation of balanced scorecard in achieving company performance, bank performance evaluation (CAMEL method) and balanced scorecard, Prasetyono's (2001: 127) said that functional management contribution in the implementation of company strategy on performance achievement of manufacturing company based on balanced scorecard approach is $98.30 \%$ and partially production management, marketing management, financial management, research and development (R\&D) management, and human resource management contributes positively and significantly, with research and development management (R\&D) contributed the highest.

Research in the implementation of balanced scorecard in manufacturing and banking companies shows the difference. Functional management in manufacturing companies includes production, marketing, finance, research and development and human resources management; while functional management in banking includes credit management, credit supervision and recovery management, and fund and services management. The use of balanced scorecard assessment method in developing CAMEL method variable in assessing bank performance focused on financial performance, while balanced scorecard method is based on financial and non-financial aspects and its development. The problem formulation is how much the implementation of credit management strategy; credit supervision and recovery management; as well as direct and indirect fund and services management give influence to bank performance achievement based on balanced scorecard approach.

\section{METHODS}

The research object consisted of two independent variables, namely the implementation of credit management strategy $\left(\mathrm{X}_{1}\right)$, implementation of credit supervision and recovery management strategy $\left(\mathrm{X}_{2}\right)$, and implementation of fund management and service strategy $\left(\mathrm{X}_{3}\right)$ and a dependent variable that was bank performance achievement based on balanced scorecard approach (Y). The research method was explanatory case study with the population of the heads of divison in all branch offices (BO) of Bank Bjb in 2016 in West Java as much as 62 Branch Offices. Each BO of Bank Jabar has three main functional areas namely credit, credit supervision and recovery and funds and services led by the manager or head of department.

Sampling method used was purposive sampling with the consideration of the distance of research sample location closer to where the researcher and each member of sample is homogeneous with the status same as the Head of Division at BO of PT Bank Jabar to produce representative conclusion of the population. The minimum number of samples was taken using the Yamane formula involving 48 heads of division in 16 BO of Bank Bjb.

The type of data used was cross-section data with primary and secondary data sources. Primary data sources came from the respondents through the distribution of questionnaires and interviews. Respondents were functional managers (heads of divisions) in each BO of PT Bank Jabar selected as samples who were the Head of Credit, the Head of Credit Supervision and Recovery, and the Head of Funds and Services. Secondary data used documentation technique from Bank Jabar in the form of financial data (financial report) and nonfinancial data (data of objectives, mission and general strategy of company, bank products and services, branch office along with its organizational structure) and Bank Indonesia in the form of financial data (banking data in West Java) and non-financial data (Law and Decree on National Banking). Operationalization of variables is shown in Table 1. The method of analysis used is the path analysis.

\section{RESULTS}

The results of data analysis using path analysis are shown in Table 2.

Tabel 2. Path Coefficient

\begin{tabular}{lll}
\hline Path Coefficient $\mathrm{X}_{1}$ on $\mathrm{Y}$ & $\mathrm{p}_{\mathrm{Y} . \mathrm{X} 1}$ & 0.4922 \\
Path Coefficient $\mathrm{X}_{2}$ on $\mathrm{Y}$ & $\mathrm{p}_{\mathrm{Y} . \mathrm{X} 2}$ & 0.5517 \\
Path Coefficient $\mathrm{X}_{3}$ on $\mathrm{Y}$ & $\mathrm{p}_{\mathrm{Y.X} 3}$ & 0.5087 \\
\hline
\end{tabular}


Results of calculation for multiple determination coefficient, multiple correlation coefficient, coefficient of determination of other variables towards $\mathrm{Y}$, and path coefficient of other variables towards $Y$ are shown in Table 3.

Tabel 3. Multiple Determination Coefficient

\begin{tabular}{lcc}
\hline Multiple Determination Coefficient & $\mathrm{R}_{\text {Y.X1X2X3 }}^{2}$ & 0.9176 \\
$\begin{array}{l}\text { Multiple Correlation Coefficient } \\
\begin{array}{l}\text { Coefficient of Determination of Other } \\
\text { Variables towards Y }\end{array}\end{array}$ & $\mathrm{p}_{\mathrm{Y} . \mathrm{X} 1 \mathrm{X} 2 \mathrm{X} 3}^{2}$ & 0.9579 \\
$\begin{array}{l}\text { Path Coefficient of Other Variables } \\
\text { towards Y }\end{array}$ & 0.0824 \\
\hline
\end{tabular}

The calculation results are shown in Figure 1.

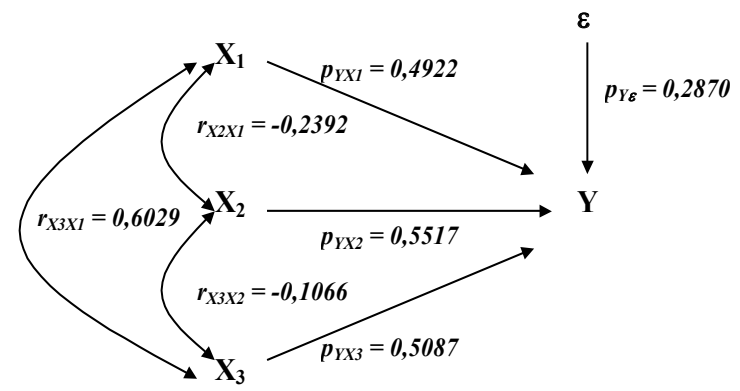

Figure 1. Path Analysis Result

Based on simultaneous test, $\mathrm{F}_{\text {count }}>\mathrm{F}_{\text {table }}$ then $\mathrm{H} 1$ is accepted or $\mathrm{H} 0$ is rejected. It meant there was an influence of strategy implementation by functional management simultaneously on bank performance achievement based on Balanced Scorecard approach.

Based on partial test, $\mathrm{t}_{\text {count }}>\mathrm{t}_{\text {table }}$ then $\mathrm{H} 1$ is accepted or $\mathrm{H} 0$ is rejected. (a) The magnitude of direct influence of $\mathrm{X}_{1}$ variable on $\mathrm{Y}$ variable is $24.23 \%$, (b) the indirect influence of $\mathrm{X}_{1}$ variable through $\mathrm{X}_{2}$ variable on $\mathrm{Y}$ variable is $-6.49 \%$, and (c) the indirect influence of $X_{1}$ variable through $\mathrm{X}_{3}$ variable on $\mathrm{Y}$ variable is $15.10 \%$. Therefore the total influence of $\mathrm{X}_{1}$ variable on $\mathrm{Y}$ variable is amounted to $32.83 \%$ (positive).

Based on the partial test, $t_{\text {count }}>t_{\text {table }}$ then $H 1$ is accepted or $\mathrm{H} 0$ is rejected. (a) The direct influence of $\mathrm{X}_{2}$ variable on $\mathrm{Y}$ variable is $30.43 \%$, (b) the indirect influence of $\mathrm{X}_{2}$ variable through $\mathrm{X}_{1}$ variable on $\mathrm{Y}$ variable is $-6.49 \%$, and (c) the indirect influence of $\mathrm{X}_{2}$ variable through $\mathrm{X}_{3}$ variable no $\mathrm{Y}$ variable equal to $-2.99 \%$. Therefore the total influence of $X_{2}$ variable on Y variable is amounted to $20.95 \%$.

Based on the partial test, $\mathrm{t}_{\text {count }}>\mathrm{t}_{\text {table }}$ then $\mathrm{H} 1$ is accepted or $\mathrm{H} 0$ is rejected. (a) The direct influence of $\mathrm{X}_{3}$ variable on $\mathrm{Y}$ variable is $25.88 \%$, (b) the indirect influence of $\mathrm{X}_{3}$ variable through $\mathrm{X}_{1}$ variable on $\mathrm{Y}$ variable is $15.10 \%$, and (c) the indirect influence of $\mathrm{X}_{3}$ variable through $\mathrm{X}_{2}$ variable on $\mathrm{Y}$ variable is $-2.99 \%$. Therefore the total influence of $\mathrm{X}_{3}$ variable to $\mathrm{Y}$ variable is amounted to $37.99 \%$.

\section{DISCUSSION}

Many experts view that the process of strategy management consists of three stages namely strategy formulation, strategy implementation and strategy evaluation and control. They have a linked relationship (David, 2016). One of the levels of corporate management strategy is functional-level strategy executed by functional managers. According to Certo and Peter (2016: 115), the bank's functional managers are responsible for the implementation of the strategy according to their fields including credit distribution, credit supervision and recovery, as well as the collection of funds and the provision of bank services.

The measure used as an indicator of bank performance achievement with balanced scorecard approach measures performance with four perspectives namely finance, customers, internal business processes and learning and growth. The implementation of strategies is executed by functional managers together affect the achievement of a company's performance. Seeing the results of data analysis and testing of statistical hypotheses that the implementation of strategies by credit managers, credit supervision and recovery managers, and fund and service managers together affect the achievement of bank performance based on balanced scorecard approach at BO of Bank Bjb in West Java by $91.76 \%$.

The magnitude of this influence belongs to a very high category of influence, so that the achievement of BO of Bank Bjb's performance in West Java is strongly influenced by the implementation of the strategies executed by functional managers. Programs, budgets, and procedures are the stages of strategy implementation in functional areas ran by functional managers showing a positive influence on the achievement of $\mathrm{BO}$ of Bank Bjb's performance in West Java. The performance achievement of BO of Bank Bjb is directly influenced by the ability of the Heads of Division in implementing the strategy undertaken related to the main activities in fund raising, credit distribution and provision of bank services.

The performance achievement of BO of Bank $\mathrm{Bjb}$ in West Java is not influenced by the strategy implementation by heads of division only, but there are other variables that influence, that is equal to $8.24 \%$. Another variable that can affect the achievement of $\mathrm{BO}$ of Bank Bjb's performance is the ability of Branch Head in leading the organization of the company. In accordance with the organizational structure in the Branch Head of Bank Bjb oversees the head of division consisting of the Head of credit, the Head of credit supervision and recovery, as well as the Head of fund and services and has the authority to regulate various operational activities in BO of Bank Bjb which they led as a whole including regulating the process the main activities of bank companies run by the Heads of Division in strategy implementation. This means that 
the success of the main banking activities run by the Heads of Division in the implementation of the strategy to achieve the banking performance objectives is also determined by the ability of Branch Heads in leading.

Based on the result of analysis, the influence of credit management strategy implementation on bank performance achievement based on balanced scorecard approach at BO of Bank Bjb in West Java is 32.83\%. Indirect influence through the implementation of credit supervision and recovery management strategy is $-6.49 \%$ and implementation of fund management and service strategy is $15.10 \%$. This means that credit managers in implementing their strategies are not positively influenced by the implementation of credit supervision and recovery manager's strategy but are also influenced by the implementation of fund and services manager's strategy.

In essence, the linkage of strategy implementation is executed by credit managers with fund and service managers in achieving the performance of BO of Bank Bjb in West Java on the main activities in fund raising, credit distribution and provision of bank services. Credit distribution activities are the authority of credit managers, while fund-raising activities and the provision of bank services are the authority of fund and service managers. This authority is used as the main foundation for credit managers and fund and services managers to implement strategies in accordance with their functional areas. In running the credit distribution, they should always coordinate with fund and services managers because credit funds will be distributed to customers is the result of fund raising which is the authority of fund and services managers so that credit managers can implement the strategy.

Based on result of data analysis, the influence value of implementation of credit supervision and recovery management strategy on bank performance achievement based on balanced scorecard approach at BO of Bank Bjb in West Java is $20.95 \%$. The indirect influence through the implementation of credit management strategy is $-6.49 \%$ and through the implementation of strategy by fund and service managers on the achievement of BO of Bank Bjb's performance in West Java is $-2.99 \%$. This shows that the implementation of credit supervision and recovery manager's strategy is not influenced by the implementation of fund and service manager's strategy.

The absence of linkages in the implementation of credit supervision and recovery manager's strategy with credit manager's and fund and service manager's in achieving the performance of $\mathrm{BO}$ of Bank Bjb in West Java demonstrated its primary function of overseeing and saving the credits under which credit supervision and recovery managers are based on a common strategy applied by BO of Bank Bjb in West java. Based on the general strategy applied by BO of Bank Bjb in West Java is to increase revenues through selective and careful expansion of financing with an emphasis on small businesses without neglecting financing to medium and large enterprises with an emphasis on companies that support small business development.

The main activities that are run by credit supervision and recovery managers related to bank debtors, such as monitoring the development of the debtor, providing early warning about the decline in credit quality that is expected to contain risks for the bank, guidance to the debtor to meet their obligations, rescheduling of credit repayment, restructuring of credit terms, reorganization, recapitalization and credit recall.

Based on the result of data analysis, the influence of implementation of fund and service management strategy on bank performance achievement based on balanced scorecard approach at BO of Bank Bjb in West Java is $37.99 \%$. The indirect influence of the implementation of credit management strategy on the achievement of BO of Bank Bjb's performance in West Java is $15.10 \%$ and the indirect influence of the implementation of credit supervision and recovery management strategy on the achievement of BO of Bank Bjb's performance in West Java is $-2.99 \%$. This means that fund and service managers in implementing their strategy of achieving BO of Bank Bjb's performance in West Java are influenced by the implementation of credit manager's strategy but not influenced by the implementation of credit supervision and recovery strategy. The linkage between implementation of the strategy executed by fund and service managers with credit managers in an effort to achieve the performance of BO of Bank Bjb in West Java is based on the main activities of banking.

Fund raising activities and the provision of bank services are the authority of fund and service managers, while credit distribution activities are the authority of credit managers. This authority is used as the main basis for fund and service managers as well as credit managers to implement strategies in accordance with their functional areas. Fund and service managers raise funds in particular and the provision of funds continues to coordinate with credit managers, as the result of fundraising from customers is the main capital in credit distribution which is the authority of the credit manager. Therefore the fund and service managers in implementing their strategy to achieve the performance of BO of Bank Jabar in West Java are influenced by the implementation of strategy executed by credit managers.

Functional managers together coordinate in implementing strategies to achieve company performance goals (Stoner and Freeman, 2012: 206). Functional bank managers consisting of credit managers, credit supervision and recovery managers, and funds and service managers are a common force in implementing strategies in line with their functional areas of achieving company performance goals. In order to support strategy implementation, managers 
develop the programs, budgets and procedures they need (Wheelen and Hunger, 2015: 185).

Conditions supporting the use of balanced scorecard approach in measuring the achievements of Bjb's performance in terms of quality and sustainable growth are implemented through long-term corporate policy through (a) fundraising, through cross selling and infrastructure development models such as sales force and employment, (b) In the field of credit, the focus is on improving non-performing loans (NPLs) through increased billing, early warning system implementation and accelerated execution of collateral. In essence, what is done by bank Bjb is a policy of selective growth, (c) In the field of services, the focus is to develop electronic and information-based services directed to providing safe, fast, easy, and consumer-oriented banking services; (d) Human Resources, capacity building through a number of trainings, implementation of punishment and reward systems are also continuously improved, (e) In the financial sector, improving the Cost Center function to monitor expenditures, resulting in efficient performance, (f) Enhancing the role of internal audit as a strategic business partners for management and the whole ranks of bank in achieving their objectives. Based on the determination of targets in the general strategy draft of Bank Bjb, it is understood that they all have a relationship with the benchmarks in balanced scorecard perspective namely finance, customers, internal business processes, and learning and growth, (g) With the use of balanced scorecard approach it can be used as an alternative consideration in measuring the achievement of Bank Bjb's performance.

\section{CONCLUSION}

Based on the results of data analysis and hypothesis testing of 16 BO of Bank Bjb in West Java with the number of respondents as many as 48 functional managers, it can be concluded that the implementation of strategies executed by credit managers; credit supervision and recovery managers; and fund and service managers jointly affect the bank performance achievement based on balanced scorecard approach at BO of Bank Bjb in West Java by $91.76 \%$.

Implementation of credit management strategy has a direct effect on the bank performance achievement based on balanced scorecard approach at BO of Bank Bjb in West Java by $32.83 \%$. Indirect influence through the implementation of credit supervision and recovery management strategy is $-6.49 \%$ and implementation of fund management and service strategy is $15.10 \%$. This means that the credit manager in implementing the strategy is not positively influenced by the implementation of the credit supervision and recovery management strategy but is positively influenced by the implementation of fund and service manager's strategy.
Implementation of credit supervision and recovery management strategy directly affect the achievement of bank's performance based on balanced scorecard approach at BO of Bank Bjb in West Java by $20.95 \%$. The indirect influence through the implementation of credit manager's strategy is $-6.49 \%$ and through the implementation of fund and service manager's strategy on the achievement of BO of Bank Bjb's performance in West Java is $-2.99 \%$. This indicates that the implementation of credit supervision and recovery manager's strategy is not influenced by the implementation of credit manager's and fund and service manager's strategy.

Implementation of fund and service management strategy on bank performance achievement based on balanced scorecard approach at BO of Bank Bjb in West Java is 37,99\%, indirect influence through implementation of credit management strategy is $15.10 \%$ and through implementation of management credit supervision and recovery strategy is $-2.99 \%$. This means that fund and service managers in implementing their strategy of achieving BO of Bank Bjb's performance in West Java are influenced by the implementation of credit manager's strategy but are not influenced by the implementation of credit supervision and recovery management strategy.

\section{REFERENCES}

Achyar Iljas. 2012. Peran Perbankan Indonesia dalam Mendukung Sektor Riil dalam Era Otonomi Daerah. Forum Diskusi: Daya Saing Dunia Usaha dan Perbankan dalam Era Otonomi Daerah. Bank Indonesia, Bandung.

Anthony, Robert N. and Vijay Govidarajan. 2014. Management Control Systems. Sixteenth Edition. International Edition. McGraw-Hill Inc. Boston.

Bank Indonesia. Surat Keputusan Direksi Bank Indonesia No.13/PBI/2011 tentang Penilaian Tingkat Kesehatan Bank Umum.

Certo, Samuel C. and J. Paul Peter. 2016. Strategic Management: Concepts and Applications. Tenth Edition. International Editions. McGraw-Hill Inc. Singapore.

David, Fred R. 2016. Strategic Management: Concepts and Cases. Seventeenth Edition. Prentice Hall International Inc. Upper Saddle River, New Jersey.

D'Souza, Renato. 2007. Application of the Balanced Scorecard in Strategy Implementation of Barclays Bank of Kenya Limited. erepository.uonbi.ac.ke

Hansen, Don R. and Maryanne M. Mowen. 2017. Cost Management. South-Western College Publishing Cincinnati. Ohio.

Ittner, Christopher D. and David F. Larcker. 2014. Innovations in Performance Measurement: Trends and Research Implications. Journal of Management Accounting Research. Vol 12. pp. 205 - 238.

Jauch, Lawrence R. and William F. Glueck. 2013. 
Bussiness Policy and Strategic Management. Fifth Edition. International Edition. McGraw-Hill Inc. Singapore.

Kaplan, Robert and David P. Norton. 2015. Translating Strategy Into Action The Balanced Scorecard. Harvard Business School. Boston.

Mghanga, D.W., 2010. Application of the balanced scorecard in strategy implementation at the Kenya Commercial Bank. erepository.uonbi.ac.ke

Mulyadi. 2015. Balanced Scorecard: Alat Manajemen Kontemporer untuk Pelipatganda Kinerja Keuangan Perusahaan. Edisi ke-6. Cetakan ke-1. Salemba Empat. Jakarta.

Nanni Jr, Alfred J., J. Robb Dixon and Thomas E. Vollmann. 2012. "Integrated Performance Measurement: Management Accounting to Support the New Manufacturing Realities". Journal of Management Accounting Research. Vol 4. pp. 1 $-19$.

Nurmadi H. Sumarta. 2013. Evaluasi Kinerja Perusahaan Perbankan yang terdaftar di Bursa Efek Jakarta dan Thailand. Perspektif: Jurnal Ilmu Ekonomi, Manajemen dan Akuntansi. Vol 5, No 2.
Desember. Hal $49-60$.

Ozturk, Elif and Coskun, Ali. 2014. A Strategic Approach to Performance Management in Bank: The Balanced Scoreboard. Accounting and Finance Research. Vol.3 No.3.

Prasetyono. 2001. Kontribusi Manajemen Fungsional dalam Implementasi Strategi Perusahaan terhadap Pencapaian Kinerja Perusahaan Manufaktur berdasarkan Pendekatan Balanced Scorecard. Tesis. Pascasarjana UNPAD, Bandung.

Shank, John K. and Vijay Govindarajan. 2015. Strategic Cost Management and The Value Chain. Readings and Issues in Cost Management. Editor: James M. Reeve. South Western Publishing and Warren Gorham \& Lamont. New York

Undang-undang No. 24 Tahun 2004 tentang Perimbangan Keuangan Antara Pemerintah Pusat dan Daerah.

Undang-undang No. 9 Tahun 2015 tentang Pemerintah Daerah.

Wheelen, Thomas L. and J. David Hunger. 2015. Strategic Management and Business Policy. 14th Edition. Prentice Hall Upper Saddle River. New Jersey.

\section{APPENDIX}

Table 1. Operationalization of Variable

\begin{tabular}{|c|c|c|c|}
\hline $\begin{array}{l}\text { VARIABLE } \\
(1) \\
\end{array}$ & $\begin{array}{l}\text { SUB VARIABLE } \\
(2)\end{array}$ & $\begin{array}{c}\text { DIMENSION } \\
(3) \\
\end{array}$ & $\begin{array}{l}\text { INDICATOR } \\
(4)\end{array}$ \\
\hline $\begin{array}{c}\text { Strategy } \\
\text { Implementation } \\
\text { (X) }\end{array}$ & $\begin{array}{c}\text { Credit } \\
\text { Management } \\
\text { Strategy } \\
\text { Implementation } \\
\left(\mathrm{X}_{1}\right)\end{array}$ & $\begin{array}{ll}\text { 1. } & \text { Credit } \\
\text { Program } \\
\text { 2. } & \text { Credit Budget } \\
\text { 3. } & \text { Credit } \\
& \text { Program } \\
& \text { Implementation } \\
& \text { Procedure }\end{array}$ & $\begin{array}{l}\text { 1. Credit Program } \\
\text { a. Credit Marketing : } \\
\text { 1) Increasing the amount and value of quality of the credit } \\
\text { 2) Making the right decision on credit request proposed by } \\
\text { debtor candidate } \\
\text { 3) Efficiency and effectiveness of the marketing of bank } \\
\text { credit products through improved services and integrated } \\
\text { promotion } \\
\text { b. Credit Administration and Documentation : } \\
\text { Improving the completeness, accuracy, and neatness of credit } \\
\text { administration and documentation, particularly in the preparation } \\
\text { of credit reports } \\
\text { c. Employee Training of Credit Division: } \\
\text { Maintaining and developing the knowledge and skills of } \\
\text { employees of credit division on an ongoing basis } \\
\text { Credit Budget } \\
\text { a. Organizational Adaptation } \\
\text { b. Full Communication } \\
\text { c. Realistic Expectations } \\
\text { d. Timeliness } \\
\text { e. Flexible Application } \\
\text { f. Individual and Group Recognition } \\
\text { g. Follow-Up }\end{array}$ \\
\hline
\end{tabular}


3. Credit Program Implementation Procedure

a. Credit Marketing :

1) Increasing the amount and value of quality of the credit

2) Making the right decision on credit request proposed by debtor candidate

3) Efficiency and effectiveness of the marketing of bank credit products through improved services and integrated promotion

b. Credit Administration and Documentation :

Improving the completeness, accuracy, and neatness of credit administration and documentation, particularly in the preparation of credit reports

c. Employee Training of Credit Division:

Maintaining and developing the knowledge and skills of employees of credit division on an ongoing basis

Source :

Wheelen and Hunger (2015:9); Siswanto Sutojo (2015:41 and 165); and Welsch (2014:30)

$\begin{array}{crl}\begin{array}{c}\text { Credit } \\ \text { Supervision }\end{array} & \text { 1. } & \text { Credit } \\ \text { and Recovery } & & \text { Supervision } \\ \text { and Recovery } \\ \text { Management } & & \text { Program } \\ \text { Strategy } & \text { 2. } & \text { Credit } \\ \text { Implementation } & & \text { Supervision } \\ \left(\mathrm{X}_{2}\right) & & \text { and Recovery } \\ & & \text { Budget } \\ & \text { 3. } & \text { Credit } \\ & \text { Supervision } \\ & \text { and Recovery } \\ & \text { Program } \\ & \text { Implementation } \\ & \text { Procedure }\end{array}$

1. Credit Supervision and Recovery Program

a. Credit Supervision :

1) Overseeing credit lending conducted by credit division in accordance with Bank Credit Policy (BCP)

2) Monitoring the progress of debtor activities and providing early warning on the decline in the quality of credits that are expected to contain risks for banks

3) Supervising credit credibility assessment in accordance with the provisions of Bank Indonesia

4) Conducting guidance to debtor, so that the debtor can fulfill their obligation to the bank

5) Monitoring and supervising in particular the validity of credit lending to debtors is in accordance with BCP

6) Monitoring the implementation of credit administration and documentation is in accordance with the established provisions

7) Monitoring the sufficiency of allowance for credit losses

b. Credit Recovery :

1) Rescheduling Program

2) Reconditioning Program

3) Reorganization and Recapitalization Program

4) Credit withdrawal by: direct billing, credit collection through credit guarantor, cooperating with other creditors, and selling asset

c. Employee Training of Credit Supervision and Recovery Section: Maintain and develop the knowledge and skills of employees of credit supervision and recovery division on an ongoing basis

2. Credit Supervision and Recovery Budget
a. Organizational Adaptation)
b. Full Communication
c. Realistic Expectations
d. Timeliness
e. Flexible Application
f. Individual and Group Recognition
g. Follow-Up 
3. Credit Supervision and Recovery Program Implementation Procedure a. Credit Supervision :

1. Overseeing credit lending conducted by credit division in accordance with Bank Credit Policy (BCP)

2. Monitoring the progress of debtor activities and provide early warning on the decline in the quality of credits that are expected to contain risks for banks

3. Supervising credit credibility assessment in accordance with the provisions of Bank Indonesia

4. Conducting guidance to debtor, so that the debtor can fulfill their obligation to the bank

5. Monitoring and supervising in particular the validity of credit lending to debtors is in accordance with BCP

6. Monitoring the implementation of credit administration and documentation is in accordance with the established provisions

7. Monitoring the sufficiency of allowance for credit losses

b. Credit Recovery :

1. Rescheduling Program

2. Reconditioning Program

3. Reorganization and Recapitalization Program

4. Credit withdrawal by: direct billing, credit collection through credit guarantor, cooperating with other creditors, and selling asset

c. Employee Training of Credit Supervision and Recovery Division:

Maintaining and developing the knowledge and skills of employees of credit supervision and recovery division on an ongoing basis

Source :

Wheelen and Hunger (2015:9); Director Decree of Bank Indonesia No.13/PBI/2011; Siswanto Sutojo (2015:193-194, and 199); and Welsch (2014:30)

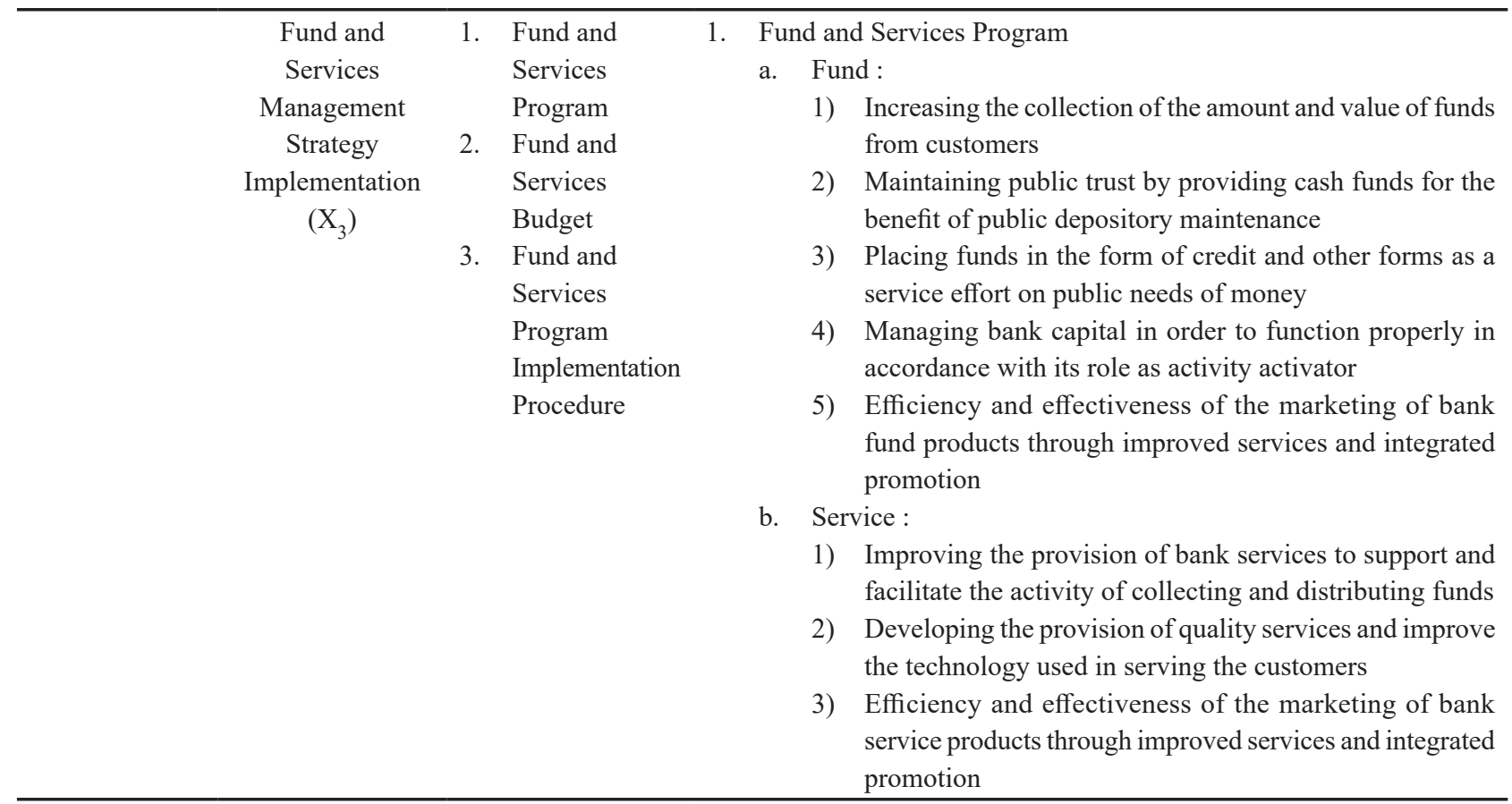


c. Employee Training of Fund and Services Division:

Maintaining and developing the knowledge and skills of employees of fund and services division on an ongoing basis

2. Fund and Services Budget

a. Organizational Adaptation

b. Full Communication

c. Realistic Expectations

d. Timeliness

e. Flexible Application

f. Individual and Group Recognition

g. Follow-Up

3. Fund and Services Program Implementation Procedure

a. Fund :

1) Increasing the collection of the amount and value of funds from customers

2) Maintaining public trust by providing cash funds for the benefit of public depository maintenance

3) Placing funds in the form of credit and other forms as a service effort on public needs of money

4) Managing bank capital in order to function properly in accordance with its role as activity activator

5) Efficiency and effectiveness of the marketing of bank fund products through improved services and integrated promotion

b. Service :

6) Improving the provision of bank services to support and facilitate the activity of collecting and distributing funds

7) Developing the provision of quality services and improve the technology used in serving the customers

8) Efficiency and effectiveness of the marketing of bank service products through improved services and integrated promotion

c. Employee Training of Fund and Services Division:

Maintaining and developing the knowledge and skills of employees of fund and services division on an ongoing basis

Source :

Wheelen and Hunger (2015:9); Muchdarsyah Sinungan (2015:80), Kasmir

(2016:107, 159 and 171); and Welsch (2014:30)

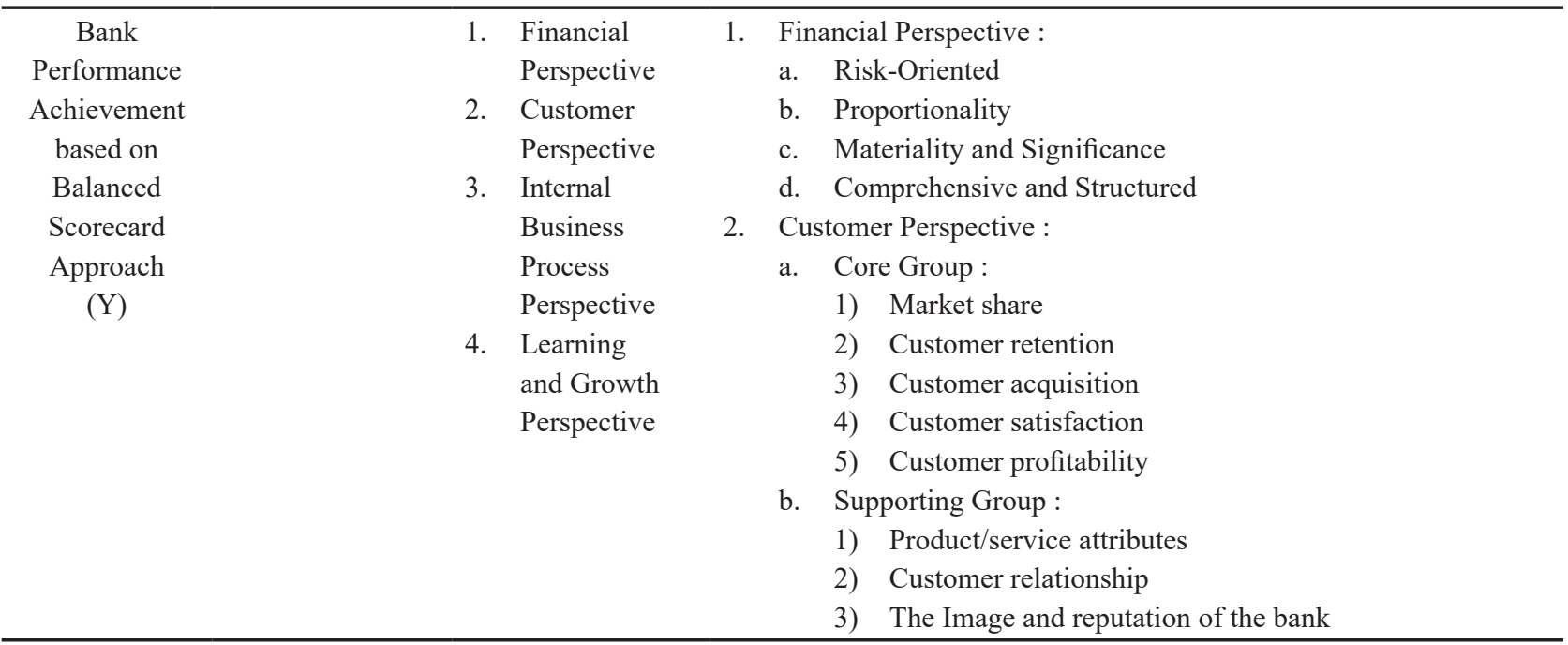


3. Internal Business Process Perspective :
a. Innovation process
b. Operation process
c. After sales service process

4. Learning and Growth Perspective :

a. Employee capability

b. Information system capability

c. Motivation, empowerment, and individual alignment with the company

Source :

Anthony and Govidarajan (2014:467); Chang and Chow (1999:396397); Hoque and James (2000:2-3); Kaplan and Norton (2015:136, and12015:44); and Mulyadi (2015:4) 